\title{
Pneumomediastinum due to High-frequency Jet Ventilation in a Near-drowned Infant
}

\author{
Mayuki Aibiki, Yoichi ShIRAKaWa, Kenji Ogli, \\ Tetsuro UefujI, Yoko TOSAKI, Satoshi Yokono, \\ Hisao Komatsu and Atsuko YoKoNo
}

\begin{abstract}
(Key words: high-frequency-jet ventilation, lung compliance, pneumomediastinum)
\end{abstract}

High-frequency jet ventilation was initially developed by Klain et al. ${ }^{1}$ and has attracted considerable recent interest as a promising new alternative method of mechanical ventilation. However, several authors have suggested that oxygenation by high-frequency ventilation depends on the mean airway pressure level in the same way as does conventional ventilation in the involved lung ${ }^{2,3}$. Furthermore, Kolton et al. demonstrated that in rabbits with surfactant removed by saline lavage, the optimal ventilation with high frequency oscillation is necessarily superimposed on the periodic lung inflations, causing an increase in mean airway pressures and hightend risk of barotrauma ${ }^{4}$. However, the combined use of high frequency ventilation (HFV) with intermittent positive pressure ventilation (IPPV) was reported to clinically improve oxygenation in acute lung disease with a lower mean airway pressure than that of conventional ventilation ${ }^{5}$. We thus applied high-frequency jet ventilation (HF JV) with IPPV to a neardrowned infant, who had been submerged in sewage in a lavatory tank, and did not

Department of Anesthesiology \& Emergency Medicine, Kagawa Medical School, Kagawa, Japan

Address reprint requests to Dr. Aibiki: Department of Anesthesiology \& Emergency Medicine, Kagawa Medical School, Miki, Kida, Kagawa, 76107 Japan repond to conventional ventilation with PEEP. Three hours after the start of HFJV with IPPV, this respiratory mode caused a critical pneumomediastinum in spite of the lowered airway pressure. In the present report, the mechanism of this pneumomediastinum is discussed.

\section{Case Report}

A 15-month-old girl accidentally fell into a lavatory tank and was submerged for approximately $5 \mathrm{~min}$. When rescued by emergency medical technicians, physical examination revealed the cessation of both spontaneous respiration and heart beat. She was transported to a hospital near her house under the resuscitation, where heart beat, spontaneous respiration and light reflex of the pupils was restored after positive pressure ventilation with oxygen and intracardiac administration of epinephrine. Heart beat was restored about $18 \mathrm{~min}$ after the accident. Five hours after the accident, she was transfered to our intensive care unit for the management of acute respiratory failure and CNS-oriented therapy.

On admission, she was in a deep coma and showed a generalized cyanosis, hyperthermia $\left(39.2^{\circ} \mathrm{C}\right.$ rectal temperature), tachycardia (230 bpm, without arrythmias), tachypnea (60/min, effortive) and hypertension (120/80 $\mathrm{mmHg})$. Moist rales were audible through- 
out both lungs. Bloody sputums smelling of feces drained from the nasotracheal tube. A chest X-ray obtained on admission demonstrated a marked infiltration in both lung fields (fig. 1). We instituted conventional ventilation using the Bourns-BP 200 (California, USA), a pressure-preset type of ventilator with ventilator setting of 40 breaths/min, total gas flow $9 \mathrm{~L} / \mathrm{min}$, peak inspiratory pressur $40 \mathrm{cmH}_{2} \mathrm{O}$, and inspired oxygen fraction $\left(\mathrm{FI}_{\mathrm{O}_{2}}\right) 1.0$ with positive endexpiratory pressure (PEEP) of $10 \mathrm{cmH}_{2} \mathrm{O}$. This respiratory mode, however, did not improve the arterial oxygenation. An arterial blood gas analysis (ABG) revealed extremely large alveolar-arterial differences of oxygen tension and a severe metabolic acidosis; $\mathrm{FI}_{\mathrm{O}_{2}}$ 1.0, pH 7.224, $\mathrm{PaCO}_{2} 32.1 \mathrm{mmHg}, \mathrm{Pa}_{2} 63.2$ $\mathrm{mmHg}$, hemoglobin saturation $86.6 \%$, and base excess $-13.7 \mathrm{mEq} / \mathrm{L}$. In spite of continuous positive pressure ventilation (CPPV) at $\mathrm{FI}_{\mathrm{O}_{2}} 1: 0$ and a frequent tracheal lavage, severe hypoxia did not improve even 1 hour after the institution of CPPV. We therefore decided to apply a high-frequency-jet ventilation (HFJV) to improve oxygenation. HFJV, using a HFOJ ventilator (Mera Corp. Tokyo, JAPAN) at a frequency of $5 \mathrm{~Hz}$, a driving pressure of $0.8 \mathrm{~kg} / \mathrm{cm}^{2}$ and an $\mathrm{FI}_{\mathrm{O}_{2}}$ of 0.8 , was superimposed on IPPV via a jet injector at the oral end of endotracheal tube. Total gas flow of the pressure-preset ventilator was reduced from 9 to $4 \mathrm{~L} / \mathrm{min}$ in order to prevent acute hyperinflation with attendant risk of barotrauma. Immediately after the employment of HFJV with IPPV, the ABG showed a dramatic improvement; $\mathrm{FiO}_{2}$ 0.8, pH 7.543, $\mathrm{PaCO}_{2} 23.2 \mathrm{mmHg}$, $\mathrm{PaO}_{2} 436.8 \mathrm{mmHg}$, hemoglobin saturation $99.8 \%$ and base excess $-0.4 \mathrm{mEq} / \mathrm{L}$. This respiratory mode, however, caused circulatory depressions. To conuteract the hemodynamic deterioration, intravascular volume loading using colloid solution and the administration of an inotropic agent (dopamine 3 $\mu \mathrm{g} / \mathrm{kg} / \mathrm{min}$ ) was performed. The ventilatory settings were also changed; the peak inspiratory pressure from 40 to $30 \mathrm{cmH}_{2} \mathrm{O}$, total flow from 4 to $3 \mathrm{~L} / \mathrm{min}$, the driving pressure of jet ventilator from 0.8 to $0.6 \mathrm{~kg} / \mathrm{cm}^{2}$ and

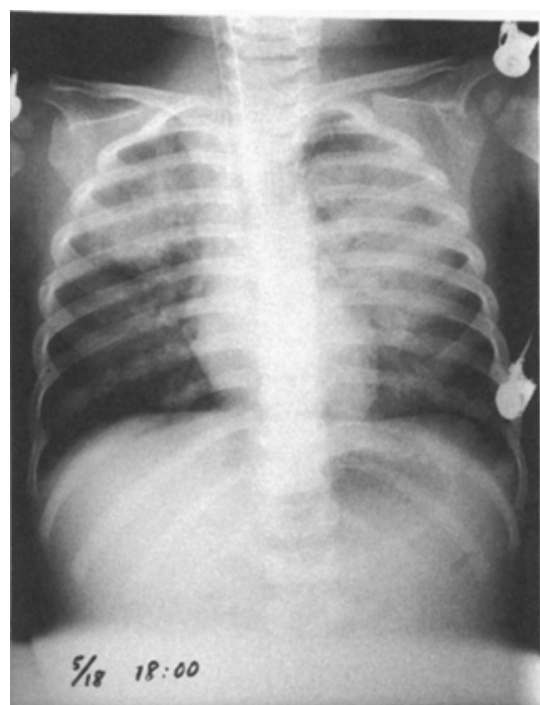

Fig. 1. A chest X-ray taken on admission shows a marked infiltration in both lung fields.

an $\mathrm{Fi}_{\mathrm{O}_{2}}$ from 0.8 to 0.4 (table 1). Thereafter, hemodynamic parameters improved and urinary output also increased. The $\mathrm{ABG}\left(\mathrm{Fi}_{\mathrm{O}_{2}}\right.$ $0.4)$ on the changed respiratory mode was pH 7.546, $\mathrm{PaCO}_{2} 24.0 \mathrm{mmHg}, \mathrm{PaO}_{2} 232.2$ mmHg, hemoglobin saturation $99.7 \%$ and base excess $-0.4 \mathrm{mEq} / \mathrm{L}$. Three hours after the start of HFJV with IPPV, despite a reduction in airway pressure, circulatory depression abruptly reappeared. A chest X-ray obtained on this event revealed hyperinflation of both lungs and a marked pneumomediastinum (fig. 2). Asthmatic wheezing was not detected and ABG did not show any aggravation; the $\mathrm{ABG}\left(\mathrm{Fi}_{\mathrm{O}_{2}}, 0.4\right)$ was $\mathrm{pH}$ 7.541, $\mathrm{PaCO}_{2} 21.0 \mathrm{mmHg}, \mathrm{PaO}_{2} 200.1 \mathrm{mmHg}$ and base excess $-4.3 \mathrm{mEq} / \mathrm{L}$. Thus, we ruled out an asthmal attack as the cause of this pneumomediastinum. In order to treat the pneumomediastinum, several respiratory settings were tried and an appropriate setting was found as follows; HFJV at a frequency of $5 \mathrm{~Hz}$, a driving pressure of $0.5 \mathrm{~kg} / \mathrm{cm}^{2}$, an $\mathrm{FI}_{\mathrm{O}_{2}}$ of 0.45 and IPPV at a peak inspiratory pressure of $22 \mathrm{cmH}_{2} \mathrm{O}$, at a rate of 20 breaths/min, total gas flow OL/min. This combined respiratory mode provided a "staircase" profile of inspiration during the closure of exhalation valve in the Bourns BP- 
Table 1. Time course of arterial blood gas analysis on 1st hospital day

\begin{tabular}{|c|c|c|c|c|}
\hline $\begin{array}{l}\text { Respiratory } \\
\text { Mode }\end{array}$ & $\begin{array}{c}\text { IPPV with } \\
\text { PEEP } \\
\text { (on admission) }\end{array}$ & $\begin{array}{l}\text { HFJV with } \\
\text { IPPV } \\
\text { (1 hr after } \\
\text { admission) }\end{array}$ & $\begin{array}{c}\text { HFJV with } \\
\text { IPPV } \\
\text { (PN developed) }\end{array}$ & $\begin{array}{c}\text { HF JV with } \\
\text { IPPV } \\
\text { (PN disappered) }\end{array}$ \\
\hline $\mathrm{pH}$ & 7.224 & 7.543 & 7.541 & 7.380 \\
\hline $\mathrm{PaCO}_{2}(\mathrm{mmHg})$ & 32.1 & 23.2 & 21.0 & 36.5 \\
\hline $\mathrm{PaO}_{2}(\mathrm{mmHg})$ & 63.2 & 436.8 & 200.1 & 102.3 \\
\hline B.E. $(\mathrm{mEq} / \mathrm{L})$ & -13.7 & -0.4 & -4.3 & -3.0 \\
\hline PIP $\left(\mathrm{cmH}_{2} \mathrm{O}\right)$ & 40 & 40 & 30 & 20 \\
\hline R.R. (breaths/min) & 40 & 40 & 30 & 20 \\
\hline T.F. (1/min) & 9 & 4 & 3 & 0 \\
\hline PEEP $\left(\mathrm{cmH}_{2} \mathrm{O}\right)$ & 10 & 0 & 0 & 0 \\
\hline D.P. $\left(\mathrm{kg} / \mathrm{cm}^{2}\right)$ & & 0.8 & 0.6 & 0.5 \\
\hline Frequency $(\mathrm{Hz})$ & & 5 & 5 & 5 \\
\hline $\mathrm{FI}_{\mathrm{O}_{2}}$ & 1.0 & 0.8 & 0.4 & 0.45 \\
\hline
\end{tabular}

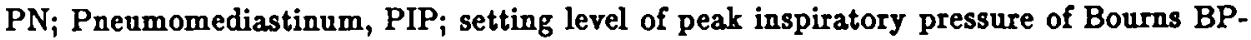
200, R.R; respiratory rate of Bourns BP-200, T.F; total flow of Bourns BP-200, D.P; driving pressure of HFOJ ventilator.

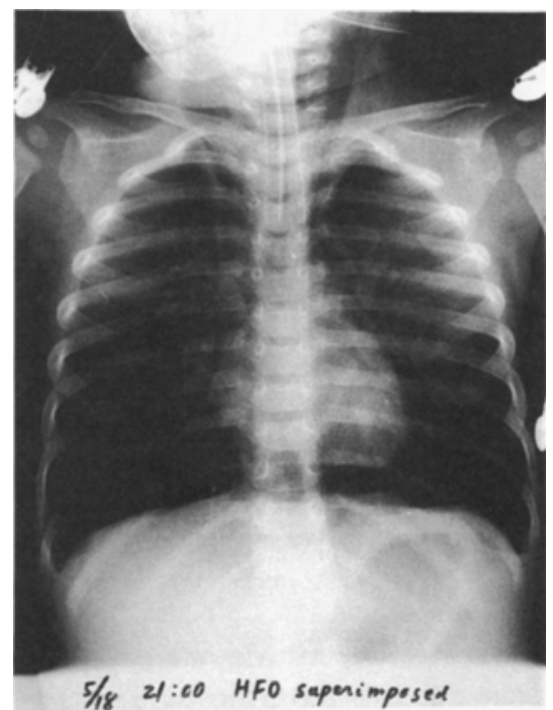

Fig. 2. A chest $X$-ray obtained 3 hours after the institution of HFJV with IPPV demonstrates bilateral lung hyperinflation and a pneumomediastinum.

200 ventilator. Heart beat gradually dropped (from 180 to $120 \mathrm{bpm}$ ), mean blood pressure increased (from 50 to $90 \mathrm{mmHg}$ ). The $\mathrm{ABG}$ on this setting was $\mathrm{pH} 7.380, \mathrm{PaCO}_{2} 36.5$ $\mathrm{mmHg}, \mathrm{Pa}_{\mathrm{O}_{2}} 102.3 \mathrm{mmHg}$, hemoglobin saturation $97.7 \%$ and base excess $-3.0 \mathrm{mEq} / \mathrm{L}$.
She was extubated on the 17th day of hospitalization and recovered her smile on the 27 th day. Seven months after the accident, although there remained involuntary movements, she was generally cheerful and leading a full and meaningful life appropriate for a child of her age.

\section{Discussion}

Rouby et al. indicated that an HFJVinduced "PEEP effect" is greater in patients with a normal or elevated time constant of the total respiratory system than in patients with a low time constant ${ }^{6}$. Therefore, it is reasonable that in patients with high airway resistance or high lung compliance, the risk of barotrauma may increase during HFJV. Simon et al. demonstrated also that during high frequency ventilation, the underestimation of the difference between mean airway pressure and mean alveolar pressure results from differences between inspiratory and expiratory impedances, depending on airway geometry, compliance, and lung volume ${ }^{7}$. It is probable that the airway resistance of our patient was high due to aspirated substances, presumably hyperosmotic, from the sewage of the lavatory tank. Thus, we cannot rule out the possibility that pneumomediastinum 
occurred in this patient is partly due to a high airway resistance. However, there was evidence that pneumomediastinum did not occur immediately after the start of HFJV with IPPV. Furthermore, the ausclutation during the pneumomediastinum did not indicate any expiratory prolongation and the ABG did not show any retension of arterial $\mathrm{CO}_{2}$ level $\left(\mathrm{PaCO}_{2} 21.0 \mathrm{mmHg}\right)$. Thus, we believe it is unlikely that high airway resistance caused this pneumomediastinum during HFJV with IPPV. It is conceivable that lung compliance when pneumomediastinum occurred may have improved: arterial oxygenation did not deteriorate even though the peak inspiratory pressure was reduced from 40 to $30 \mathrm{cmH}_{2} \mathrm{O}$, and the driving pressure of the jet ventilator from 0.8 to $0.6 \mathrm{~kg} / \mathrm{cm}^{2}$. Thus, we speculate that pneumomediastinum occurred in this patient may be mainly due to improved lung compliance, impairment to which was improved by eliminating aspirated substances through HFJV with IPPV. Therefore, it is necessary to give attension to the potential development of barotrauma especially when HFJV with IPPV is employed in an infant with initially low lung compliance which later improves.

We have reported the clinical course of an infant with severe hypoxia and deep coma after. nearly drowning in a lavatory tank. Although we applied HFJV with IPPV while controlling hemodynamic parameters safely for 3 hours, this ventilatory mode elicited a marked abrupt pneumomediastinum in spite of a reduction in airway pressure. Therefore, we urge physicians to beware of the onset of barotrauma especially when HFJV with IPPV is applied to an infant with low lung compliance that later improves.
Acknowledgement: The authors are grateful to Dr. Shozo Koyama, Professor of Department of Physiology, Division 2, Shinshu University School of Medicine, for his valuable advice.

(Received Apr. 14, 1988, accepted for publication Jul. 13, 1988)

\section{References}

1. Klain M, Smith RB: High frequency percutaneous transtracheal jet ventilation. Crit Care Med 5:280-287, 1977

2. Thompson WK, Marchak BE, Froese AB: High-frequency oscillation compared wtih standard ventilation in pulmonary injury model. J Appl Physiol 52:543-548, 1982

3. Kumar BS, Beney $K$, Jastremski $M$, Nieman G, Bredenberg C: High-frequency jet ventilation versus conventional ventilation versus conventional ventilation after surfactant displacement in dogs. Crit Care Med 12:738-741, 1984

4. Kolton M, Cattran CB, Kent G, Volgyesi $G$, Froese AB, Bryan C: Oxygenation during High-frequency ventilation compared with conventional mechanical ventilation in two models of lung injury. Anesth Analg 61:323-332, 1982

5. Verma TK, Wilson RS, Pontoppidan H: Use of high frequency ventilation in parallel with controlled mechanical ventilation in acute lung disease. Am Rev Respir Dis (suppl) 124:110, 1981

6. Rouby JJ, Simonneau G, Benhamou D, Sartene R, Sardnal F, Deriaz H, Duroux $P$, Viars P: Factors influencing pulmonary volumes and $\mathrm{CO}_{2}$ elimination during Highfrequency jet ventilation. Anesthesiology 63:473-482, 1985

7. Simon BA, Weinmann GG, Mitzner W: Mean airway pressure and alveolar pressure during High-frequency ventilation. J Appl Physiol 57:1069-1078, 1984 